\title{
VANESSA JOOSEN (RED.) CONNECTING CHILDHOOD AND OLD AGE IN POPULAR MEDIA
} Jackson: University Press of Mississippi, 2018 (256 s.)



Antologin som genre har sina för- och nackdelar. Lyckade antologier belyser ett ämne från flera perspektiv, och skribenternas olika ämnestillhörigheter, temperament och stil blir en tillgång som skapar både bredd och djup. Som bäst blir det när ämnet är relativt avgränsat - när flera forskare belyser samma punkt med olika strålkastarljus. Bidragen börjar tala med varandra istället för att tala bredvid varandra. Mindre lyckade antologier brukar snarare vara uppbyggda på motsatta sättet - ämnet är brett och skribenternas bidrag drar åt så olika håll att ingen fördjupning sker. Artiklarna talar då bredvid, eller förbi, varandra och själva temat eller ämnet blir undflyende.

Antologin Connecting Childhood and Old Age in Popular Media är ett exempel på en antologi som fungerar. Kanske beror det på att den baserar sig på en workshop som arrangerades av nätverket Cultural History of Children's Media 2015. När man träffas och presenterar pågående forskning för varandra snarare än skickar in bidrag till anonyma "Call for papers" finns i alla fall chansen att skribenterna ska vilja tala med varandra även i text. Ovan nämnda workshop måste ha varit en lyckad sådan för denna antologi präglas just av ett sammanhang och gemensamt intresse för ett avgränsat ämnesområde, trots att forskarna kommer från olika delar av världen - Japan, Sydkorea, Taiwan, Holland, USA, Belgien och Frankrike - och tillhör olika ämnesdiscipliner.

Ämnet är visserligen inte så litet: det som står på spel är hur relationer mellan generationer skildras i olika narrativ. Mer specifikt handlar det om hur ålderdom och barndom, äldre och unga, skildras i populärkulturella narrativ som film, TV, litteratur och reklam. Den utmärkta och i området initierade inledningen av redaktören

(C)2019 M. Jönsson. This is an Open Access article distributed under the terms of the Creative Commons Attribution-Noncommercial 3.0 Unported License (http://creativecommons.org/ licenses/by-nc/3.0/), permitting all non-commercial use, distribution, and reproduction in any medium, provided the original work is properly cited. Citation: Barnboken - tidskrift för barnlitteraturforskning/Barnboken - Journal of Children's Literature Research, Vol. 42, 2019 http://dx.doi.
org/10.14811/clr.v42i. 375 
Vanessa Joosen ringar in en än tydligare frågeställning. Hon menar att barndom och ålderdom i modern populärkultur tillskrivs liknande egenskaper och associeras med varandra. Båda grupperna beskrivs ofta som fysiskt svaga, i behov av särskild vård och omsorg, eller som att de besitter en viss typ av visdom eller moralisk kompass som vuxenvärlden saknar. Idén att "gamla är som barn" är, menar flera av forskarna i antologin, en så stark figur i vårt tänkande att den kan betraktas som en "rotmetafor" för att tala med George Lakoff och Mark Johnson. Hur denna rotmetafor reproduceras i mediaprodukter från västvärlden och från östasiatiska länder står alltså i centrum för antologins texter som alla har ett fokus på 1900-talets populärkultur.

Artiklarna är samlade i tre kluster där det första behandlar litteratur, det andra film och det tredje TV. I det första klustret ingår fem artiklar, skrivna av litteraturvetare. De första tre undersöker sagor och klassiska berättelser för barn som haft stort inflytande. Ingrid Tomkowiak undersöker Johanna Spyris roman Heidi från 1880 och barnkaraktärens relationer till åldringar. Tomkowiak menar att dessa relationer kompletterar bilden av Heidi som självuppoffrande givare. I relation till de äldre blir hon också en mottagare av omsorger och kunskap. Mayako Murai jämför bröderna Grimms västerländska sagor med japanska folksagor. Till skillnad från de västerländska sagorna tillåts äldre spela huvudroller i många japanska sagor och Murai diskuterar vad detta innebär. Elisabeth Wesseling granskar Hector Malots Sans famille från 1878. Hon undersöker Malots skildring av ålder i relation till naturalismen som litterär strömning och hur ålder fungerar som social kategori: alltid sammanflätad med identitetsmarkörer som klass, genus och nationalitet.

De två näst följande artiklarna behandlar mer samtida litteratur. Helma Van Lierop-Debrauwer diskuterar motivet dödshjälp i de två nederländska barnböckerna De regels van drie (2013) av Marjolijn Hof och Lang zal ze leven (2014) av Koos Meinderts. Hon menar att båda dessa böcker bjuder in barnläsaren att reflektera över äldres livsvillkor men på olika sätt: den ena vill överbrygga gapet mellan ung och gammal, den andra förstärker det indirekt genom att reproducera fördomar mot äldre. Redaktören själv, Vanessa Joosen, granskar kopplingen mellan barndom och åldrande i Jonathan Safran Foers Extremely Loud and Incredibly Close (2005). Joosen menar att det är en ovanlig bok för vuxna så till vida att den ger stort utrymme åt barnkaraktären, vars perspektiv står i dialog med de äldres. I en narratologisk analys visar hon hur glappen i de olika karaktärernas berättelser stärker det övergripande temat som handlar om vikten av att kommunicera över (generations)gränser. 
I nästa kluster ryms tre artiklar om film och adaptioner. Den första är skriven av litteraturvetaren Emily Murphy och handlar om taiwanesiska fiktioner och deras fokus på spänningar och konflikter mellan generationer, orsakade av modernitetens och globaliseringens krafter. Murphy visar att filmen Starry Starry Night (2011) och Chang Ta-Chuns bok Wild Child (1996) ger en mer problematisk bild av relationen mellan olika generationer än vad västerländska narrativ gör: här handlar det mycket om svårigheten i att växa upp och axla vuxenhet på grund av ekonomisk och social ojämlikhet som placerar unga i beroendepositioner. Den andra artikeln är skriven av Sung-Ae Lee och handlar om sydkoreansk film. Lee lyfter fram skildringen av barns relationer till far- och morföräldrar som symptom på hur moderniseringen och urbaniseringen bryter ner familjestrukturer. I sydkoreanska filmer skildras hur barn - på grund av att föräldrarna måste söka försörjning i städer - å ena sidan lämnas i äldre släktingars vård, och å andra sidan får ta hand om de äldre. Lee visar hur barn och gamla gestaltas både som maktlösa och marginaliserade grupper, men också som möjliga bundsförvanter i tider av ekonomisk modernisering. Den tredje artikeln i detta kluster är skriven av Lincoln Geraghty och handlar om filmversionerna av Kalle och chokladfabriken (2005) och Paddington (2014). Geraghty visar att konceptet "familjefilm" producerar optimistiska skildringar av åldersöverskridande relationer.

Det sista klustret i antologin handlar om TV och hur mediet skapar diskurser om ålder direkt riktade till yngre respektive äldre tittare. Mariano Narodowski och Verónica Gottau undersöker tv-serien The Simpsons (1989-). Författarna menar att The Simpsons parodierar bilden av den amerikanska familjen och på ett ironiskt sätt förhåller sig till idén om att den äldre generationen skulle ha något att erbjuda den yngre i form av visdom och erfarenhet. De äldre är här snarare pinsamma och löjeväckande och serien skildrar på så sätt en historisk förändring där maktbalansen mellan gammal och ung förändras. I en artikel om tv-serien Mad Men (2007-2015) diskuterar Cecilia Lindgren och Johanna Sjöberg de ambivalenta roller som far- och morföräldrar spelar i egenskap av både möjliggörare för barns utforskande av vuxenvärlden och gränsvakter för barndomen i serien. Relationen mellan barn och gamla är här givande för båda parter men den är också normbrytande och potentiellt farlig. Även medieforskarna Gökçe Elif Baykal och Ilgim Veryeri Alaca undersöker hur far- och morföräldrar representeras, men denna gång i turkiska tecknade tv-serier. De menar att dessa serier porträtterar traditionella åldersnormer som inte svarar mot publikens verklighet, vilket fors- 
karna menar är problematiskt. Anna Sparrman, professor vid Tema Barn vid Linköpings universitet, undersöker hur ålder görs när barn samtalar om sexualiserad reklam riktad till vuxna där heterosexuella åldersöverskridande par porträtteras. I samtalen reagerade barnen negativt på de åldersöverskridande relationerna och beskrev dem som äckliga eller löjeväckande. Barnen förhöll sig dock inte negativt till de äldre personerna per se, bara till vissa relationer mellan ung och gammal.

Som synes är spännvidden stor i denna antologi, både vad gäller ämnen och frågeställningar. Ändå hålls volymen som sagt samman genom ett gemensamt intresse för just relationen mellan unga och gamla, mellan barndom och ålderdom. Flera av de narrativ som undersöks målar upp en konflikt där barn och gamla så att säga sitter i samma båt och står i opposition mot normen - det vill säga de professionellt aktiva medelålders vuxna. Joosen menar i avslutningen på sin inledning att både gamla och unga i dessa berättelser skildras som "becomings" snarare än "beings" (utifrån Nick Lees terminologi). Det betyder att de gestaltas som människor i förändring och växande. Det är inte helt uttalat i antologin, men som läsare anar man att de enda som kanske inte förändras är de "vuxennormativa vuxna" - det vill säga de som både barn och åldringar indirekt kontrasteras mot. Är det något jag gärna hade sett att denna antologi hade utforskat mer är det just detta - den paradoxala tystnad som uppstår kring de norm-vuxna i dessa berättelser. Vad betyder det att förändring och utveckling skildras genom barndom och ålderdom snarare än vuxenhet i moderna berättelser? Vad säger det egentligen om moderniteten? Om dess ideologiska omförhandling av värden och identiteter? Om dess ekonomiska och geografiska söndrande effekter? Dessa frågor finns med här och där i antologin, men jag hade gärna sett en samlande diskussion där just frånvaron av vuxna problematiserades. Boken ställer indirekt viktiga frågor om det moderna samhällets paradoxala förhållande till vuxenhet och vuxenblivande. Vuxenheten är på en och samma gång totalt dominerande och samtidigt avvecklad och detroniserad.

Sägas ska dock att jag aldrig hade fått dessa tankar om jag inte läst denna spännande antologi som innehåller så många uppslag och så många tankeväckande idéer kring relationen mellan barndom och ålderdom i modern populärkultur. Det är en klok bok på många sätt. Den är genomtänkt och väl avvägd både vad gäller material, perspektivval och strukturen på artiklarna. Det finns en fin balans mellan teori och empiri i de flesta artiklarna - möjligen undantaget Sparrmans något teoritunga (om än metodologiskt intressanta) artikel. Den redaktionella bearbetningen verkar vara väl genomförd 
- det enda undantaget är Baykal och Alacas artikel som har en märkligt normativ ton som harmonierar dåligt med de övriga bidragens öppet resonerande karaktär. Den geografiska spridningen på studierna är också klok - att se exempelvis de västerländska Hollywoodfilmernas lätt nostalgiska skildringar av relationen mellan barndom och ålderdom kontrasterad mot de mer konfliktorienterade taiwanesiska fiktionerna ger intressanta perspektivförskjutningar.

De två artiklar jag funderat mest över och vill kommentera lite mer utförligt är Joosens och Geraghtys bidrag. Joosens artikel handlar om Foers bästsäljande roman från 2005 som översatts till en mängd språk och även filmatiserats. I boken berättas en historia ur tre perspektiv; den nioårige Oskar Schells och hans båda farföräldrars. Joosen gör en narratologisk analys som lyfter fram de motsägelser, klyftor och inkonsekvenser som finns i de tre olika berättelserna. Hon argumenterar övertygande för att detta berättartekniska grepp - att blottlägga gapen mellan generationerna - harmonierar väl med romanens tema om vikten av att kommunicera över (generations) gränser. Även resonemangen om den inskrivna läsaren, eller den tänkta publiken, är intressanta i Joosens artikel. Det kan tyckas vara en självklarhet, men Joosen lyfter fram att den inskrivna vuxna läsaren påverkar skildringen av relationen mellan barndom och ålderdom. Ämnen som inte skulle komma upp i en barnbok - exempelvis vissa traumatiska eller sexuella minnen - är en del av vuxenromanen och ger en annan dimension av bilden av barndomen och ålderdomen. Joosens undersökning inspirerar till fler jämförelser mellan barn- och vuxenlitteraturens sätt att gestalta barndom och ålderdom. En av Joosens centrala poänger skulle jag dock vilja polemisera mot. Hon menar att Foers roman är ett undantag i vuxenlitteraturen vad gäller skildringen av relationer mellan barn och vuxna där barnkaraktären får en central plats. Medan det $\mathrm{i}$ barnlitteraturen finns en hel korpus av sådana skildringar - där dessa relationer dessutom ofta beskrivs i positiva termer - verkar vuxenlitteraturen (med några få undantag) enligt Joosen ointresserad av desamma. Här tycker jag Joosen blir för snäv och generaliserande i sitt synsätt och missar många vuxenromaner där barnperspektivet spelar en central roll. I en skandinavisk kontext är det bara att tänka på alla de självbiografiska romaner som undersöker relationen mellan barn, föräldrar och äldre, och relationen mellan det unga och det åldrande författarjaget. Jag tänker på exempelvis Karl-Ove Knausgårds eller Linn Ullmans romaner där barnets blick är avgörande. Även Kerstin Thorvall och Barbro Lindgren skriver berättelser för vuxna där barnkaraktärer kan ha centrala roller - för att inte tala om Tove Jansson och hennes Sommarboken (1972). Detta är nu ingen avgörande kritik mot Joosens 
artikel, snarare ger den mig lust att läsa fler undersökningar liknande denna - kanske särskilt om författarskap som ägnar sig åt så kalllad crosswriting.

Geraghtys artikel om hur Hollywoods familjefilmer gestaltar relationer mellan barn och gamla finner jag också särskilt läsvärd. Han undersöker filmversionerna av Kalle och chokladfabriken och Paddington och gör mängder av intressanta iakttagelser. Geraghty menar att rotmetaforen "gamla är som barn och barn är som gamla" är stark i internationell familjefilm. I filmerna beskrivs hur äldre karaktärer - Kalles farfar i Kalle och chokladfabriken respektive Mr. Gruber (och delvis Mr. Curry) i Paddington - pånyttföds i kontakten med barn: de vitaliseras genom lek och fantasi. Barnen (Kalle och Paddington) gör en motsatt rörelse - de finner genom äventyret en inre mognad och blir mer ansvariga individer. Riktigt intressant blir det när Geraghty diskuterar vad dessa relationer innebär ideologiskt. Han menar att båda berättelserna ger uttryck för kulturella ideal om familj, arbete, nostalgi och nation. Vikten av att ingå i en familj är ett centralt tema för både Kalle och Willy Wonka, och så även för Paddington och familjen Brown. I båda filmerna poängteras att detta att ingå i en familj kräver hårt arbete och känslomässig ansträngning. Ideologin kring lönearbete - vikten av att ha ett sådant och att vara produktiv - märks genom både Kalles och farfars resa i berättelsen. Farfar revitaliseras under äventyret och blir produktiv och användbar för samhället igen. Kalle börjar arbeta hårt för att hitta den gyllene biljetten, och blir till slut inte bara en del av konsumtions- och produktionskulturen utan till och med fabriks- och företagsägare. På ett likande ideologikritiskt sätt visar Geraghty hur skildringen av Paddington (och även Mr. Gruber) kan läsas som en berättelse om hur en immigrant ska assimileras in i den engelska kulturen. Vikten av att anpassa sig för att kunna slå sig ner och hitta ett sammanhang understryks. Det fina med Geraghtys analys är dock att den lyckas hålla två bollar i luften samtidigt. A ena sidan visar Geraghty att dessa filmer är delar av en större ideologiproduktion kring fenomen som familj, arbete och nation, å andra sidan visar han också hur dessa filmer - genom att koppla ihop barn med gamla - förstärker vikten av resan och möjligheten att gå från ett tillstånd till ett annat. Familjefilmerna visar att man inte är instängd i sin position, det är möjligt att som gammal få ny livskraft och att som barn nå en personlig mognad. Det är möjligt att både vara och att bli. 